\title{
NOTE
}

\section{CONFLICT OF INTERESTS AS A FACTOR IN THE ALLOWANCE OF REPRESENTATIVES' CLAIMS IN INSOLVENT CORPORATE REORGANIZATIONS}

\section{INTRODUCTION}

The negotiations for the consummation of a plan of reorganization among the trustees, creditors and stockholders have been likened to a "horse trading" session. ${ }^{1}$ The trustee is bound to prepare a plan which is fair, equitable and feasible to all classes, ${ }^{2}$ while the several classes of security holders each seek to make the greatest possible gain for themselves, often at the expense of the others. However, the wide diffusion of security holders has created a situation wherein the single holder is helpless in protecting his own interests or pleading his own cause. The plight of the small investor is accentuated where he is uninformed and unskilled in the intricacies of finance, and where his investment is so small that it becomes either impossible or improvident for him to expend the funds necessary to prosecute his claim or defend his position. It is to satisfy this need that protective committees have become an important element in reorganization proceedings. ${ }^{3}$ Under the committee system, individuals join together to represent a class of security holders and solicit proxies from these holders for authorization to negotiate in their behalf. ${ }^{4}$ Generally, one committee is formed to represent each class; however, if certain holders believe that the existing committee is under a special influence and is not properly representing the class a second committee within the class may be formed. ${ }^{5}$ De-

1. 2 Dewing, The Financtal Policy of Corporations 1273 (5th ed. 1953).

2. 52 STAT. 890,891 (1938), 11 U.S.C. $\$ \$ 569,574$ (1952). If the indebtedness of the debtor, liquidated as to amount and not contingent as to liability, is $\$ 250,000$ or over, the bankruptcy court is required to appoint a disinterested person to serve as trustee. If the indebtedness is under $\$ 250,000$ the court has the option to appoint a trustee or to continue the debtor in possession. 52 STAT. 888 (1938), 11 U.S.C. $\$ 556$ (1952). The trustee is not only an officer of the court and possessed of the powers and duties associated with equity receivers, 52 STAT. 884 (1938), 11 U.S.C. $\$ 515$ (1952), but he has, in addition, very real responsibilities and duties assigned to him by the Bankruptcy Act. He is authorized to operate the debtor's business, 52 STAT. 892 (1938), 11 U.S.C. \& 589 (1952), investigate and assemble information concerning the debtor and its affairs, 52 STAT. 890 (1938), 11 U.S.C. $\$ \$ 567(1)$, (2) (1952), disseminate such information to the court, creditors and stockholders, 52 STAT. 890 (1938), 11 U.S.C. $\$ 567(5)$ (1952), and to assemble the ingredients of and prepare the plan for submission to the court. (1937).

3. See SEC, II Report on Protective and Reorganization Committees 1-2

4. 2 Dewing, op. cit. supra note 1 , at 1270-81.

5. Id. at 1272 . 
pending upon the nature of the class which they are representing, protective committees may perform several functions: ${ }^{6}$ (1) mobilize security holders to secure control over the indenture trustee and demand that he pursue their proper remedies under the circumstances; (2) check on the reorganization trustee in the exercise of his duty to administer the debtor's estate; (3) examine the pre-default history of the corporation to discover assets of the estate in the form of claims against the former management; (4) investigate the possibility of claims of the corporation and the security holders themselves against bankers; (5) participate in the negotiation of a reorganization plan; and (6) marshal assents or dissents to a proposed plan so that it may be consummated or defeated. If a committee is not formed one or more security holders may authorize an individual, often an attorney, to serve as their representative in the proceedings.

In order to properly carry out these tasks, it is clear that a committee which represents a particular class must have exclusive loyalty to that class. The importance of exclusive loyalty also applies to attorneys for committees, attorneys for individuals and other representatives of individual claimants.

Conflicting loyalties may arise where the representative of a class is allied with another group whose interests are adverse to those of the members of the represented class, or where the personal pecuniary interests of the committee members or attorney are adverse to those of the individuals or class represented. In either situation it seems obvious that the representative will not exercise his best efforts in the furtherance of the cause of the parties relying on him.

Considering the inability of uninformed, small security holders to guard against exploitation of their rights by a representative who has other interests in the reorganization proceedings, Congress and the courts should adopt prophylactic measures to prevent representatives from serving conflicting interests. These measures should be prophylactic, i.e., come into operation when it is shown that a situation exists in which it is more likely than not that a conflict of interests will arise, since it would be difficult for the aggrieved security holder to prove that his rights were adversely affected. Under existing legislation the courts might deny compensation to representatives serving conflicting interests, ${ }^{7}$ or Congress might find it necessary to enact special provisions in this area to insure that the fair and equitable plan of reorganization envisioned by the Bankruptcy Act is achieved.8 The purpose of this Note is to examine the extent to which

6. For a more detailed discussion of these functions see SEC, II REPORT ON Protective and Reorganization Committees 2-7 (1937).

7. The Chandler Act provides that the judge may allow reasonable compensation for services rendered and reimbursement for proper costs and expenses incurred in the reorganization proceedings to referees, masters, trustees, committees or representatives of security holders and their attorneys. 52 STAT. 900 (1938), 11 U.S.C. $\S \S 641,642(1952)$.

8. 52 Stat. 890,891 (1938), 11 U.S.C. $\$ \$ 569,574$ (1952). 
these sanctions have been adopted, the form which they take, and the situations to which they have been applied.

\section{Representation of Persons or Classes Whose Interests Are}

\section{CONFLICTING}

In this section are considered the factual situations in which the representative of a class is allied with another group whose interests are in conflict with those of the represented class. Such a conflict can arise by the formal representation of two or more classes by a single representative or by the representative's independent alliance with another group by reason of employment, business association, etc. The most significant example of the latter type is the situation in which the representative committee is composed of members of the management of the debtor, or of the underwriters of the debtor's defaulted bonds or other securities. In such a case it might be contended that the presence of the debtor's management and the debtor's investment bankers on a protective committee is advantageous to the security holders. The member of the management of the debtor, if only to save his own reputation, is often interested in the future well-being of the corporation, while the underwriters may promote the rehabilitation of the debtor because they wish to regain the good will of the customers to whom they have sold the debtor's defaulted securities, or because they feel a moral responsibility to further their customers' interests: Moreover, since both have an intimate knowledge of the functional and financial peculiarities of the debtor, their assistance can be valuable to committees, especially in those reorganizations in which the independent trustee, who is charged with the duty of formulating the plan, has had no recent connection with the debtor.

On the other hand, it should be noted that security holders are not necessarily forced to a choice of either depositing their securities with a banker-management group or being practically, if not technically, excluded from the reorganization. Other men of comparable ability could be found to head a committee, ${ }^{9}$ or the security holders might content themselves to remain represented by the independent reorganization trustee. ${ }^{10}$ Such a solution would seem preferable since experience with reorganizations conducted under section $77 \mathrm{~B}^{11}$ has shown that where banker-management committees have been active the interests of security holders depositing with them have often been adversely affected. Protective committees serving

9. See text at note 5 supra.

10. Bondholders may also rely on the indenture trustee to represent them. Furthermore, under chapter $X$ neither the court nor the security holders are dependent upon the banker-management group for information concerning the debtor since the court can now call upon the Securities and Exchange Commission for a report upon the feasibility and fairness of prospective reorganization plans. Under section 172 the court must submit such plans to the SEC if the debtor's liabilities exceed $\$ 3,000,000$; if liabilities do not exceed $\$ 3,000,000$ the court has the option to submit or not. However, in neither case are the recommendations of the SEC binding upon the courts. 52 STAT. 890 (1938), 11 U.S.C. $\$ 572$ (1952).

11. Act of June 7, 1934, c. 424, § 77B, 48 Stat. 911. 
such conflicting interests have been frequently interested, for example, in gaining compensation or in protecting only the management of the debtor and the underwriters of the defaulted securities. ${ }^{12}$ Counsel fees, committee memberships, and other types of patronage were frequently awarded to the debtor's management and to other parties previously connected with the debtor to insure their cooperation. ${ }^{13}$ Such committees are in a position to conceal the previous negligence and fraud of the underwriters and the management, and to gain for the underwriters the flotation of the new corporation's securities. They have sometimes worked to maneuver their employers into the post reorganization management, ${ }^{14}$ and to secure large fees for themselves and their employers. ${ }^{15}$ Thus, although security holders may not be technically defrauded when their committees have adverse motives, their interests are obviously endangered. Despite the existence of some incontestable advantages in having banker-management committees, it would seem that they are overbalanced by the undesirable results which are likely to follow from their actions.

However, although the old section $77 \mathrm{~B}^{18}$ authorized the bankruptcy court to confirm a plan of reorganization if satisfied that, among other things, reorganization expenses are "reasonable," 17 the court did not consider whether or not the claimants served individuals whose interests conflicted. In In re Paramount Publix Corp., ${ }^{18}$ for example the court awarded compensation to a committee dominated by an underwriter without considering the issue of disallowing compensation because the claimant had served conflicting interests. The same result was reached in Cromzell v. Curtis ${ }^{19}$ in which a bondholders' committee had been formed by the underwriters of the defaulted issue and served by counsel to the debtor, despite the fact that the argument of conflicting interests was urged upon the court. In In re Milwaukee Lodge ${ }^{20}$ compensation was awarded to a committee employing the indenture trustee as depository, despite the fact that the indenture trustee is bound to represent all holders alike. In both the Paramount Publix and the Milwankee Lodge cases the courts felt that, provided the services of the claimants were valuable, the claimants' affiliations with conflicting interests did not forfeit their rights to compensation. ${ }^{21}$

12. SEC, I Report on Protective and Reorganization Committees 865 (1937). 13. Id. at $872-73$. $552(1940)$.

14. Carey \& Higgs, Reorganization-The Last Chance, 34 ILr. L. Rev. 549,

15. SEC, I Report on Protective and Reorganization Committees 866 (1937).

16. Act of June 7, 1934, c. 424, $\$ 77 \mathrm{~B}, 48$ STax. 912. Section 77B is the predecessor of chapter X of the Chandler Act, 52 Stat. 883 (1938), 11 U.S.C. $\$ \$ 501-676$ (1952).

17. $I d$. at 917.

18. 83 F.2d 406 (2d Cir. 1936).

19. 99 F.2d 810 (2d Cir. 1938).

20. 83 F.2d 662 (2d Cir. 1936).

21. Compensation has been denied, however, when the fee claimant has committed actual fraud. In re De Ran, 260 Fed. 732 (6th Cir. 1919). 
More recently the Supreme Court has recognized these considerations in determining compensation in the leading case of Woods $v$. City Natl Bank \& Trust Co. ${ }^{22}$ Claims for compensation were filed under Chapter $\mathrm{X}^{23}$ against the debtor by an indenture trustee, the members of a bondholders' committee, and the committee's counsel. The committee, which was originally organized by the indenture trustee, had as its most active members employees of the indenture trustee's corporate reorganization department as well as employees of an underwriter heavily interested in the debtor's stock and under threat of suit for defrauding the bondholders. The same firm of attorneys retained by the indenture trustee was employed by the committee. Thus, the interlocking personnel of the committee and the indenture trustee represented the depositing bondholders and the nondepositing bondholders ${ }^{24}$ and a large stockholder who sought a favorable position in the reorganization at the expense of both. Adopting a strict rule in order to foreclose the "tendency to evil" 25 implicit in such cases, the Court held that a fiduciary ${ }^{26}$ serving interests conflicting with those of his cestuis may receive reimbursement for proper expenditures ${ }^{27}$ but may not receive compensation for services regardless of his good faith. It should be noted at this juncture that the Court did not rely on any specific provision of the Bankruptcy Act to reach this result; instead the decision was based on the equity powers of bankruptcy courts. ${ }^{28}$

The denial of compensation to creditor's representatives serving conflicting interests may prove effective in keeping the debtor's management and security underwriters from taking part in chapter $\mathrm{X}$ proceedings.

22. 312 U.S. 262 (1941).

23. 52 StAT. 900 (1938), 11 U.S.C. $\S 642$ (1952).

24. The interests of the depositing bondholders may well be adverse to those of the non-depositing bondholders. For example, if the depositing bondholders are in favor of reorganization they would be interested in having a low value placed upon the debtor's property so that they may gain control of the debtor to the exclusion of all other classes. On the other hand, if the non-depositing bondholders are opposed to reorganization they may be in favor of a sale of the property for the satisfaction of their claims, 52 STAT. 895 (1938), 11 U.S.C. $\$ 216(7)$ (b) (1952), in which case they would want a high upset price set upon the debtor's property.

25. 312 U.S. at 268.

26. The relationship between a bondholder's committee and the depositing bondholders has been described as one of trust, agency, agency coupled with an interest, syndicate, bailment and assignment. "It is safe to say that the relationship is contractual and that it is fiduciary, but a more accurate generalization is impossible." Rogers, Rights and Duties of the Committee in Bondholders' Reorganizations, 42 HARV. L. REV. 899, 928-29 (1929). Of course, these terms are labels for the legal consequences which result when they are used. As descriptive terms they are not determinative of legal results in specific reorganization situations.

27. Expenditures for which the courts may order reimbursement must have been actual money payments, made "in furtherance of a project exclusively devoted to the interests of those whom the claimant purported to represent" and must "have clearly benefited the estate." Woods v. City Nat'l Bank \& Trust Co., 312 U.S. 262, 268 (1941). In view of the attitude of the Supreme Court it is probable that bankruptcy courts will not be allowed to award compensation under the label of liberal expenditures.

28. Chapter $X$ provides that the provisions of chapters $I$ to VII shall apply to proceedings under chapter $X$ so long as they are not inconsistent with the provisions of chapter X. 52 STAT. 883 (1938), 11 U.S.C. $\$ 502$ (1952). Chapter II invests courts of bankruptcy with jurisdiction at law and equity. 52 STAT. 842 (1938), 11 U.S.C. §11(a) (1952). 
The importance of the compensation 'motive is indicated by the virtual nonexistence of 'sècurity committees in railroad reorganizations during the period in which committee fees were not awarded. ${ }^{29}$ ' Insofar as the sanction is effective, independent groups of secirity holders will be enicouraged to form their own committees. ${ }^{30}$ Moreover, since thesé claims are subject to court approval, the application of this sanction is 'relatively easy' to administer.

The doctrine of the Woods case has been extended to apply to the situation in which one member of a law firm acted as local associate counsel for a preferred shareholders' committee, while another member of the same firm served as local counsel for a debenture committee. ${ }^{31}$ The court denied compensation to each attorney since there was a "possibility" of a conflict, despite the fact that each attorney was found to be fully. unaware of the other's participation in the proceedings. This case would seem to be a logical extension of the Woods decision, and it would further seem that the court properly' applied the sanction of disallowance of fees. The alleged advantages of expertise and overreaching personal motives' to pursue a proper course of conduct, which were found to exist in the bankermanagement situation, ${ }^{32}$ are not present when an "outsider" such as an attorney 'represents' persons with adverse interests. On the other hand, the disadvantages which were found in the former situation are also present here.

The Woods case seemed to establish an acceptable and desirable sanction for the control of committee conduct in corporate reorganization proceedings ; ${ }^{33}$ however, it was apparently ignored by Judge Learned Hand

29. See Israels, Some Problenis of Policy and Procedure in the Conduct of Reorganization.Proceedings, 89.U. PA. L. REv. 63, 82 (1940). "The insurance companies, savings.banks and other institutional holders of railroad securities have organized for their own protection, but their interests are not and cannot be precisely similar to those of the 'smaller investor." Ibid. Apparently "today, however, fees are awarded to committee members in railroad reorganizations. 49 STAT: 911, 11 U.S.C. $\$ 205$ (c) (12) (1952).

30. Aided by their 'exclusive-possession of lists of the debtor's security holders the banker-management group was able to solicit and obtain deposits of securities before independent groups were able to organize. Although section 165 of chapter $\mathrm{X}$ invests the bankriptcy court with the power to order the disclosure of lists of the debtor's security holders in the hands of whosoever they may be, only by discouraging these "insiders" from acting at all can the formation of independent committees be encouraged.

31. In re Midland United Co., 64 F. Supp. 399 (D. Del. 1946), aff'd, 159 F.2d 340 (3d Cir. 1947).

32. See text at p. 1141 stipra.

33. If the prospect of a denial of compensation is not sufficient to discourage the representation of conflicting interests, other powers are available to the court as a means of avoiding abuse. For example, the court may apply the provisions of the act which authorize it, "if the acceptance or failure to accept a plan by the holder of any claim or stock is not in good faith," to disqualify such claim or stock for the purpose of determining the requisite majority for the acceptance of a plan. 52 STAT. 894 (1938), 11 U.S.C. $\$ 603$ (1952). In addition, bankruptcy courts through the exercise of their equity powers may disqualify the committee from acting in the proceedings. In re International Ry., 86 F. Supp. 546 (W.D.N.Y. 1949); In re Realty Associates Securities Corp., 61 F. Supp. 574 (E.D.N.Y. 1945). 
in deciding Silbiger $v$. Prudence Bonds Corp. ${ }^{34}$ The claimant represented several "deficit" series bondholders and obtained an award for them. In a subsequent proceeding he represented several "surplus" series bondholders and secured approval of a plan which resulted in substantially defeating the prior award to the "deficit" series bondholders. The case indicates that the "deficit" holders did have some representation at the hearing concerning the petition of the "surplus" holders, and that the result reached at the hearing would have been the same no matter who represented either side. ${ }^{35}$ The court held that, whereas in an ordinary suit inter partes an attorney who represents opposing interests is debarred from receiving any fee from either, ${ }^{30}$ an exception to this rule should be made in a corporate reorganization where it can be shown that the evil of conflicting representation is mitigated because "the client [prejudiced by the attorney's divided allegiance] is otherwise adequately protected, and the attorney is not paid in any part by the party whose side he has opposed." ${ }^{37}$ Finding these conditions present in the case at bar, despite the representation of conflicting interests, the case was remanded to the district court with instructions to allow the fee provided it was reduced by at least one-third of the amount of the prior award.

Although it might be argued that the Woods case and the Silbiger case are so clearly distinguishable by their facts that they are not necessarily inconsistent, it is submitted that, because of the underlying theory of the Supreme Court in the former case, the two cases reach opposite results. The Woods case, in establishing a prophylactic rule, seems to compel complete denial so long as the relationship of dual representation of persons with adverse interests is present. Neither the good faith of the representative in entering into the proceeding nor any beneficial results which might have accrued as a result of his participation are considered by the court under this theory. On the other hand, the Silbiger case, in establishing a remedial device, seems to apply a rule of reason. In reaching its decision the court carefully examined the consequences which flowed from the relationship. It used this factor in determining the extent of the penalty which it would impose upon the attorney. Although it is not enunciated in the cases, the contrary results may possibly be explained on the theory that both courts believe that a penalty should be imposed when there is a "conflict of interests," the Supreme Court taking the view that there is a "conflict of interests" when the relationship alone is present, while the Second Circuit believes that there is no "conflict of interests" unless there is harm done. Each court then penalizes the extent of the "conflict of interests" present in a given case. Thus, in a case in which an attorney represented two par-

34. 180 F.2d 917 (2d Cir.), cert. denied, 340 U.S. 813 (1950).

35. Id. at $921,923-24$.

36. The court indicates that this would be the rule "no matter how successful his labors." Id. at 920 .

37. $I d$. at 921 . 
ties with adverse interests equally well without any discernible harm accruing to either, securing full awards for each, the Supreme Court might disallow compensation in full, but the Second Circuit might permit full compensation.

It would seem that, assuming some sanction is desirable to prevent the representation of conflicting interests in reorganization proceedings, the Woods case reaches the better result. Under the threat of complete disallowance committees and attorneys will consider carefully whether it is worth the risk to represent persons with adverse interests, while under Judge Hand's theory of partial disallowance according to the circumstances, the representative may be tempted to take a calculated risk. Moreover, the difficulties of administration of Hand's theory make it practically unworkable. The court is faced with the almost impossible task of weighing how "unreasonable" the conflict of interest is. Once this is done it must consider how much to reduce the fee which has been established. The difficulty of this task is accentuated upon consideration of the already existing nebulous standards which are applied in setting fees. ${ }^{38}$ Furthermore, in view of the fact that section $606^{39}$ permits any security holder to be represented in the proceedings, it is not difficult for an attorney so inclined to find a client whom he might nominally represent in almost any case. If the law permits representatives, as the proceedings progress, to desert their clients and shift to the representation of other unrepresented claimants whom they discover have claims with a chance of greater success (where their chances of a substantial fee might be better), the interests of investors tend to become secondary; the interests of representatives, primary. ${ }^{40}$ While not suggesting that this evil was present in the Silbiger case, the decision does encourage the tendency to evil in other cases. ${ }^{41}$ Indeed, the nature of corporate reorganization proceedings is such that, ${ }^{42}$ rather than affording room for relaxing exceptions from the standards applicable to an

38. The courts apply the following standards: the extent and nature of the services; the time and labor involved; the character and importance of the matter in hand; the value of the property or the amount of money involved; the learning, skill, and experience exercised; the results accomplished; losses sustained by security holders; the ability to pay; and the absoluteness or contingency of the fees. Comment, 5 Mramr L.Q. 146, 147 (1950). See also 6 Colirer, Bankruptcy 4496-513 (14th ed. 1947). Meyers, Appellate Review of Attorney Allowances in Chapter $X$ Reorganizations, 53 CoLUM. I. REv. 1039 (1953).

39. 52 Stat. 894 (1938), 11 U.S.C. §606 (1952).

40. See SEC, I Report on Protective and Reorganizatton Committees 236-42 (1937), where it is pointed out that in the absence of judicial scrutiny over counsel fees this situation was apparently of frequent occurrence in reorganizations, since the reorganization afforded "counsel great opportunity for enterpreneurial activity." The impression gained was "that reorganizations are frequently designed for the benefit of lawyers."

41. For elaboration of this argument see Brief for the RFC as Intervening Party and the SEC as Amicus Curiae, pp. 7-8, Silbiger v. Prudence-Bonds Corp., 340 U.S. $813(1950)$. The argument of the possibility of "shifting clients" seems somewhat unreal in light of the severe sanctions imposed by local bar associations for carrying out such practices.

42. See text at notes 1-6 supra. 
inter partes relationship, ${ }^{43}$ it requires, as the Supreme Court has held, the application of the highest standards of conduct, characterized by undivided loyalty.

Although the number of cases is limited, the most recent pronouncement in this area adopted the Silbiger approach. In Chicago \& West Tozems Ry. v. Friedman ${ }^{44}$ a plan of reorganization was filed by a competitor of the debtor. The claimant served as attorney for the bondholders' committee, while the claimant's firm was retained as counsel for the competitor. The court found that "the historic conflict of interests between a prospective seller and a prospective buyer was present." 45 The court then held that although authority exists for the disallowance of all fees, it would adopt the less harsh rule of a penalty of less than full forfeiture. ${ }^{46}$ This case indicates that the courts feel that they now have a choice between applicable sanctions to apply when a claimant represents conflicting interests.

It would seem that because of the split of authority relating to the proper sanction to be imposed upon persons who represent conflicting interests in corporate reorganization proceedings, either legislative action in the form of an amendment to the Bankruptcy Act or ultimate clarification of the problem by the Supreme Court is required. While it seems that the doctrine of the Woods case represents the most effective sanction of those presently applied, its prime failing is that the penalty for participating in an undesirable transaction is imposed only after the act has been done. While the threat of this penalty will deter some individuals from representing conflicting interests, it would seem that Congress should consider adopting more positive devices specifically aimed at the prevention of the conduct before it occurs. A suggested procedure is that a person should be required to secure the approval of the bankruptcy court before he is permitted to serve as a committee member, attorney for a committee, or individual security holder's representative. ${ }^{47}$ If the reorganization proceeds over an

43. See text at note 36 supra. There seems to be no reason why attorneys in corporate reorganizations should practice in a less exacting climate than corporate directors. Presbyterian Church v. Plainfield Trust Co., 139 N.J. Eq. 501, 52 A.2d 400 (Ch. 1947) (testamentary trustees); Meinhard v. Salmon, 249 N.Y. 458,164 N.E. 545 (1928) (commercial joint adventurers); Wendt v. Fischer, 243 N.Y. 439, 154 N.E. 303 (1926) (broker); and Munson v. S., G. \& C.R.R., 103 N.Y. 58, 8 N.E. 355 (1896), exemplify only a few of the different types of relationships which have been held to strict standards. However, the court in the Silbiger case attempts to find a distinction between corporate reorganization proceedings and ordinary suits. "The purpose of the prohibition [of the denial of compensation for the representation of conflicting interests] is to insure the advantage to the client of the undivided allegiance of his attorney; and in situations in which the client is otherwise adequately protected, and the attorney is not paid in any part by the party whose side he has opposed, the result is inevitably a penalty." $180 \mathrm{~F} .2 \mathrm{~d}$ at 921 . It is questionable whether this distinction is meaningful.

44. 230 F.2d 364 (7th Cir. 1956).

45. Id. at $368-69$.

46. Whereas in the Silbiger case the court remanded the case to the district court to determine the penalty, the court in the instant case decided the extent of the penalty itself. Id. at 369 .

47. Of course the procedure which is ultimately adopted should include provisions for notice, hearing and the like, so as to satisfy constitutional requirements of procedural due process of law. 
extended period of time, the representatives should be required to file additional reports so as to secure continued approval of the court. The court, in granting or denying approval of both the initial and subsequent petitions, should consider the applicant's present and past affiliations with the debtor and with the reorganization proceedings, i.e.; whether he has served in the management of the debtor, or as the debtor's underwriter, or as a representative. 'While these factors are by no means exclusive, more specific standards should not be established. To do so would probably result in overlooking many possible situations in which a conflict of interests exists or might exist, and thus permit the ingenious person who discovered a new device to escape the precepts of the act. If the court upon examination of the petition determines that there is then existing a conflict of interest on the part of the representative, or the possibility that such a conflict might develop, the person should be disqualified from assuming the representative capacity. Under this proposal the depositing security holders would be assured of the complete integrity and undivided service and loyalty of their representatives; the bankruptcy court and the Securities and Exchange Commission would be assured that all plans submitted for approval have been negotiated by persons whose interests were to benefit but one client; and the representatives would be assured that they will be adequately compensated for their work, and not be in fear that some act committed by them will completely bar them from their just awards. Moreover, this proposal will strike at the person'who serves to achieve certain goals fully aware of the fact that if he so act's he will not be compensated.48 The safeguards imposed by this suggested procedure would seem to satisfy all objections that the Woods-type sanction as presently applied is too severe.

\section{Personal Pecuniary Interests of the Representative Are Adverse to Those of -the Person or Class Being Represented}

The interests of security holders may also be adversely affected where the representative personally possesses or trades in securities of the debtor. Consideration will indicate that this can be found in eight basic type transactions: (1) the representative owned securities prior to entering into the proceedings and he retains them throughout the proceedings; $(2)$ the representative purchases securities during the proceedings and retains them for the duration of the proceedings; (3) the representative owned securities prior to entering into the proceedings but sold them during the course of the proceedings; and (4) the representative owning no securities prior to entering into the proceedings purchases and sells securities during the proceedings. These four transactions become eight when it is recalled that the se-

48. Since one of the policies of the act would seem to be to protect the unwary and naive, the fact that many security holders are generally uninformed and unskilled in the intricacies of finance should indicate that even if the depositing security holders were aware of the representative's conflicting interests there should be no defense to the application of the Woods sanction. 
curities possessed or traded in by the representative may be either of the same or of a different class from that owned by the individuals or class he is representing. Of course, in any given case combinations of these transactions may be found.

Apparently based on the assumptions that most of the aforementioned transactions are undesirable, and that compensation is one of the principal motives for representatives entering into reorganization proceedings, Congress, in the Chandler Act, adopted section $249^{49}$ which provides:

"Any persons seeking compensation for services rendered or reimbursement for costs and expenses incurred in a proceeding under this chapter shall file with the court a statement under oath showing the claims against, or stock of, the debtor, if any, in which a beneficial interest, direct or indirect, has been acquired or transferred by him or for his account, after the commencement of such proceeding. No compensation or reimbursement shall be allowed to any committee or attorney, or other person acting in the proceedings in a representative or fiduciary capacity, who at any time after assuming to act in such capacity has purchased or sold such claims or stock, or by whom or for whose account such claims or stock have, without the prior consent or subsequent approval of the judge, been otherwise acquired or transferred." 50

49. 52 Stat. 901 (1938), 11 U.S.C. $\$ 649$ (1952). See SEC, General Rules and Regulations Undeg the Public Utmity Holding Company Act of 1935 Rule U-62(g)(2) (1941):

"No securities of the company or companies in reorganization, or of any subsidiary of such company, or of any other associate company thereof which may be affected by the reorganization, shall be bought or sold by or for the account of (whether as principal, agent, trustee, or otherwise) any of the persons specified in clauses (A) to (E) below, or in any transaction in which any such person has any beneficial interest, direct or indirect; nor shall any investment advice with respect to any such securities be given, directly or indirectly, by-

"(A) Any person who makes any solicitation subject to this rule; or

"(B) Any person connected with any committee or other organization formed to act under the authorization so solicited; or

"(C) Any company as defined in section 2(A) (2) of the Act controlled by any person specified in (A) or (B) above; or

"(D) Any company as so defined of which any person specified in (A)

or (B) above is an officer, director, partner or employee; or

"(E) Any person who is a partner or employee of any person specified in

(A) or (B) above."

See text and notes at notes 90, 93 infra for sanctions imposed for violation of this provision.

50. Under section 77B a few courts, although not authorized to do so by the act, sought to discourage this type of conduct through the disallowance of claims for compensation for services rendered. Thus, in In re Paramount Publix Corp., 12 F. Supp. 823 (E.D.N.Y. 1935), a member of a shareholders' committee was denied compensation for buying and selling shares and debentures of the debtor during the reorganization proceedings. In In re Republic Gas Corp., 35 F. Supp. 300 (S.D.N.Y. 1936), compensation was denied to members of a bondholders; committee who bought and sold bonds of the debtor during the proceedings, and to a committee member who bought the bonds for investment. The court rejected the defenses that the transactions were made in good faith for investment purposes 
It is clear that the statute does not cover the situation in which the representative owned securities of the debtor prior to assuming his position and retained them throughout the proceedings. Furthermore, no case has been discovered in which it was urged upon the court to deny compensation to a representative who so acted. ${ }^{51}$ Beyond this, however, it is not clear when the duty to refrain from trading begins. While the first sentence of section 249 imposes the obligation upon the representative to file a sworn statement regarding any trading from the time of filing the reorganization petition, ${ }^{52}$ the second sentence bars an allowance for trading after assuming to act in a representative capacity. Thus, a representative might trade in the debtor's securities both before or after the filing of the petition, up to the time of his employment.53 However, there is a serious question of whether he is permitted to trade after his employment but before the actual reorganization proceedings commence. In In re CosgroveMeehan Coal Corp. ${ }^{54}$ the court held that section 249 bars an allowance to a person who was a member of a bondholders' committee who traded in the bonds of the debtor after he assumed his position, but prior to the filing of the petition of reorganization. ${ }^{55}$ A contrary construction would seem to

and that the securities traded in were of the same class as those they purported to represent. The courts based their decisions on the grounds that since the statute to represent. payment of "reasonable" compensation it necessarily implies loyal and disinterested service in the interests of the persons for whom they purport to act. Section 249 has been said to codify and give general application to the rule enunicated by these courts. 6 CoLIIER, BAN KRUPTCY 4585 (14th ed. 1956).

51. Cf. In re Franklin Bldg. Co., 83 F. Supp. 263. (E.D. Wis. 1948), decided under section 212, discussed at p. 1156 infra. The claimant, a member of a bondholders' committee, purchased bonds of the debtor price to becoming a member and retained them throughout the proceedings. The court recognized his claim on the bonds in full, and refused the request made by the trustee to limit the claim to cost.

52. "Section 249 requires all persons seeking an allowance for services or expenses to file a sworn statement of the claims against or stock of the debtor acquired or transferred after commencement of the proceeding. Failure to comply results in automatic disqualification without regard to whether trading actually took place. If the affidavit is filed, however, the burden of proving trading is on him who opposes the allowance." Meyers, Appellate Review of Attorney Allowances in Chapter $X$ Reorgasizations, 53 ColuM. L. REv. 1039, 1044 (1953), and cases cited therein.

53. But an affidavit must be filed if the trading occurs after the petition is filed.

54. 136 F.2d 3 (3d Cir. 1943).

55. In the Cosgrove-Meehan case the claimant sought allowances for two distinct sets of services: (1) as a member of a bondholders' committee organized before reorganization and functioning before and after commencement of the proceeding; (2) as an "agent or trustee" (to use the words of the opinion) of the debtor prior to reorganization in salvaging the assets of a bankruptcy subsidiary of the debtor. The claimant had traded in the debtor's bonds before the institution of proceedings, but after his employment. The court denied compensation for the services first listed, but granted an allowance for the second. Regarding the first, the position was that section 249 barred an allowance to a "fiduciary" who trades after becoming such, whether or not reorganization has begun. Surprisingly, the court did not regard compensation for the second: set of services as barred by section 249 because those services were not rendered in connection with the reorganization proceeding. The opinion does not indicate whether or not all of the claimant's services on the committee were rendered subsequent to the filing of the reorganization petition. If some of the claimant's services on the committee 
fit the words of the act more closely. "No compensation . . . shall be allowed to any . . . person acting in the proceedings . . . who at any time after assuming to act in such capacity has purchased or sold such claims or stock. . . "56 While this sentence does not make it clear whether or not its application is limited to trading after the proceedings have commenced, it is submitted that the word "such" refers to the trading in the first sentence (requiring the affidavit), which is limited to trading after the commencement of the reorganization. In short, the second sentence is limited to the first. 57 Otherwise the section would reach the anomalous result of barring allowances for trading before the proceedings, but not requiring the disclosure of such activity. ${ }^{58}$

The statute has been held to be specifically applicable to compensation for attorneys for individual security holders, ${ }^{59}$ to representatives of individuals, ${ }^{60}$ to members of committees, ${ }^{61}$ and to attorneys for committees. ${ }^{62}$ It has covered the situations in which there were sales during the proceedings of prior owned securities, ${ }^{63}$ purchases during the proceedings, ${ }^{64}$ and pur-

were rendered prior to reorganization, as the report seems to indicate, the two holdings are difficult to reconcile since no compensation for such prior services was allowed. The case presents a representative who, because of trading before reorganization, forfeits his compensation for some pre-reorganization services but not for others. If, on the other hand, it is assumed that all the committee's services were rendered after the proceeding commericed, we are faced with the peculiar situation of a representative recovering compensation for services rendered prior to reorganization, although the trading occurred at that time, and being denied compensation for services rendered during the proceeding, when no trading took place. These anomalies disappear if the act is construed to apply only to trading after the petition is filed, leaving equity principles to govern prior instances of trading.

56. 52 StaT. 901 (1938), 11 U.S.C. $\$ 649$ (1952). (Emphasis added.)

57. See Meyers, Appellate Review of Attorney Allowances in Chapter $X$ Reorganizations, 53 Couvar. L. REv. 1039, 1045 (1953).

58. See In re Reynolds Investing Co., 130 F.2d 60 (3d Cir. 1942). Cf. In re Realty Associates Securities Corp., 61 F. Supp. 574 (E.D.N.Y. 1945) (fact that a member of a bondholders' committee purchased bonds of debtor during a prior proceeding under the act which was terminated by confirmation held not objectionable in the subsequent reorganization proceeding).

59. In re 188 Randolph Bldg. Corp., 151 F.2d 357 (7th Cir. 1945).

60. Finn v. Childs Co., 181 F.2d 431 (2d Cir. 1950); Otis \& Co. v. Insurance Bldg. Corp., 110 F.2d 333 (1st Cir. 1940).

61. In re Philadelphia \& Reading Coal \& Iron Co., 61 F. Supp. 120 (E.D. Pa. 1945).

62. In re Midland United Co., 64 F. Supp. 399 (D. Del. 1946), aff'd, 159 F.2d 340 (3d Cir. 1947). Cf. In re Mortgage Guarantee Co., 40 F. Supp. 226 (D. Md. 1941) (attorney for company which represented security holders awarded compensation, despite fact that the company traded in the debtor's securities); In re Colonial Util., Inc., 34 F. Supp. 223 (D. Del. 1940) (Attorney for indenture trustee was held not precluded from compensation for services rendered during reorganization despite the fact that after his appointment he sold securities of the debtor which he had acquired prior to his appointment. The court, in holding that he was not within the terms of section 249, seems to have rendered a questionable decision.)

63. Finn v. Childs Co., 181 F.2d 431 (2d Cir. 1950); In re 188 Randolph Bldg. Corp., 151 F.2d 357 "(7th Cir. 1945).

64. In re Philadelphia \& Reading Coal \& Iron Co., 61 F. Supp. 120 (E.D. Pa. 1945). 
chases and sales during the proceedings. ${ }^{65}$ The fact that the securities traded in were of the same ${ }^{66}$ or different class ${ }^{67}$ as those owned by the persons they were representing has been considered immaterial by the cases. Likewise the courts have been careful to prevent circumvention of the statute. In In re Arcade Malleable Iron Co. ${ }^{68}$ an attorney for creditors had purchased bonds of the debtor during the proceedings. He billed the creditors for his services and was paid. When the creditors sought reimbursement from the estate for expenses incurred, ${ }^{69}$ the court denied their petition because it was evident that it was "filed only for the purpose of avoiding the provisions of Section 249 which precluded, under the circumstances, compensation being allowed to their attorney." 70 Moreover, section 249 has. been construed strictly and without qualification.71 Good or bad faith, ${ }^{72}$ profit or loss on the transactions, ${ }^{73}$ the, lack of fraud or subterfuge ${ }^{74}$ are all immaterial in applying its precepts.

The disqualification has been held to reach trading in securities of corporations other than the debtor. In In re Midland United Co., ${ }^{75}$ compensation was denied to an attorney for a bondholders' committee who traded in shares of a solvent, going subsidiary corporation of the debtor which had claims against the parent. : The basis of the decision was that the attorney indirectly purchased a beneficial interest in claims against the debtor. By way of dictum the court.suggests that section 249 does not apply to trading in securities of solvent subsidiaries in the absence of claims against the parent, though this circumstance is likely to be rare. It would seem that this decision gives weight to the premise that the first sentence of section 249 limits the application of the second 'sentence, since the "indirect interest" provision appears only in the first sentence. ${ }^{76}$ :On the other hand, a more recent district court opinion looked only to the second sentence of

65. Finn v. Childs Co., 181 F.2d 431 (2d Cir. 1950); Otis \& Co. v. Insurance 'Bldg. Corp., 110 F.2d 333 (1st Cir. 1940); In re Midland United Co., 64 F. Supp. 399 (D. Del. 1946), aff'd, 159 F.2d 340 (3d Cir. 1947).

66. E.g., In re Reynolds Investing Co., 130 F:2d 60 (3d Cir. 1942); Otis \& Co. v. Insurance Bldg. Corp., supra note 65.

67. E.g., In re Midland United Co., 64 F. Supp. 399 (D. Del. 1946), aff'd, 159 F.2d 340. (3d Cir. 1947).

68. 35 F. Supp. 461 (D. Mass. 1940).

69. "The judge may allow reasonable compensation for services rendered and reimbursement for proper costs and expenses incurred by creditors and stockholders. . . 52 Stat. 900 (1938), 11 U.S.C. 643 (1952).

70. $35 \mathrm{~F}$. Supp. at 462 . The decision may rest on the proposition that "expenses" do not include attorney's fees since they are separately provided for by the act. The court does suggest, however, that the disallowance resulted from the attempted evasion of section 249 .

71. In re Reynolds Investing Co., 130 F.2d 60 (3d Cir. 1942).

72. E.g., In re Philadelphia \& Reading Coal \& Iron Co., 61 F. Supp. 120 (E.D. Pa. 1945).

73. E.g., Otis \& Co. v. Insurance' Bldg. Corp., 110 F.2d 333 (1st Cir. 1940).

74. Finn v. Childs Co., 181 F.2d 431 (2d Cir. 1950).

75. 64 F. Supp. 399 (D. Del. 1946), aff'd, 159 F.2d 340 (3d Cir. 1947).

76. See text at note 50 sitpra. 
section 249 and held that shares of a subsidiary were not claims against the debtor and accordingly awarded compensation to an attorney who traded in them. ${ }^{77}$ In reaching its decision the court did not discuss the point of whether or not the subsidiary owned claims against the parent. ${ }^{78}$

The wording of the statute and cases decided thereunder indicate that the court cannot grant its approval to the ordinary purchase or sale of securities of a debtor ${ }^{79}$ However, the statute does provide that the judge can grant his approval when "such claims or stock have . . . been otherwise acquired or transferred." 80 In the Cosgrove-Meehan case the court denied compensation to a member of a bondholders' committee who had pledged bonds of the debtor as collateral for a loan (the court hypothesized that the pledge took place prior to reorganization), the pledgee having foreclosed and sold the collateral. The court did not make clear whether this was the type transaction which it could not approve, or if it was of the type it could approve but was simply withholding approval. However, in the recent case of In re Third Avenue Transit Corp. ${ }^{81}$ the court denying compensation under similar facts held that this was the type of transaction which they could not approve. The special provision for court approval would seem to have been inserted to avoid unnecessary hardship in the case of involuntary transfer or acquisition, such as by gift, testamentary bequest, or inheritance by operation of law. While the sale by a pledgee would also seem to be involuntary, the court in the Third Avemue Transit case indicates that the claimant could have sold personal assets to avoid the foreclosure of the collateral. Whether the Court would reach the same result if it were satisfactorily proven that the representative was in such poor financial straits that the foreclosure would be unavoidable is somewhat uncertain. Even the true involuntary transfer, such as an inheritance, must still secure court approval, either before or after the event, before compensation can be awarded. Thus, it would seem that any form of acqui-

77. In re Central States Elec. Corp., 112 F. Supp. 281 (E.D. Va. 1953). The court further reasoned that to preclude trading in the shares of a subsidiary would ultimately preclude trading in the shares of any corporation in which the debtor might also own shares. This reasoning seems questionable, since it does not necessarily follow that simply because one corporation owns shares in another the latter is "subsidiary." For purposes of the Bankruptcy Act the term "subsidiary" might be defined as requiring a certain degree of control.

78. It would seem that even though a court holds that section 249 does not bar trading in shares of a subsidiary, the court's equity power might be exercised so as to bar compensation. See note 28 supra. In In re Central States Elec. Corp., silpra note 77 , the court further held that even equity would not warrant the denial of compensation.

79. E.g., Otis \& Co. v. Insurance Bldg. Corp., 110 F.2d 333 (1st Cir. 1940). See also Hearings Before the Subcommittee on the Revision of the National Bankruptcy Act of the Senate Committee on the Judiciary, 75th Cong., 2d Sess., at 80-81 (1950). However, one commentator seems to assume that judicial approval will excuse any sort of transfer. Teton, Reorganization Revised, 48 Y AIE L.J. 573, 602-03 (1939).

80. See text at note 50 stupra.

81. 159 F. Supp. 440 (S.D.N.Y. 1958). 
sition or transfer known to the law may result in disallowance of compensation and that purchase or sale does so necessarily.

A common issue in disallowance cases has been the application of the act to trading by a spouse, or by relatives, business partners, friends and other persons associated with the representatives. Compensation has been denied to a member of a preferred shareholders' committee whose $e_{j}$ business partners dealt in securities of the debtor's subsidiary, ${ }^{82}$ to a debtor's attorney whose partners dealt.in the debtor's bonds, ${ }^{83}$ to the preferred shareholders' committee chairman whose investment firm dealt in the debtor's securities for their own account, ${ }^{84}$ and to a member of a debenture holders' committee whose partner in a law firm dealt in securities of the debtor on the advice of his own investment broker. ${ }^{85}$ On the other hand, disallowance has not been held to extend to an attorney whose clierits traded in the debtor's securities, ${ }^{86}$ nor to a claimant whose investment broker had so traded. ${ }^{87}$ Literally read, the statute does not seem to support the decisions in which compensation has been disallowed. However, the usual justification, that the statute's application is necessary to prevent evasion of its precepts, ${ }^{88}$ appears convincing. Dictum in those cases in which compensation has been allowed indicates that the extension of section 249 should be applied only in those instances in which the claimant is in a position to exercise some degree of control over the persons who have traded. ${ }^{80}$.While this view seems to have considerable merit it is not entirely supported by the cases.90

Far greater uncertainty lies in the application of the section to trading by a spouse. Cases have held that where the wives of members of bondholders' committees, ${ }^{91}$ preferred shareholders' committees, ${ }^{92}$ and attorneys for committees or individuals ${ }^{93}$ had traded.in securities of the debtor the claimants should be denied compensation. Although courts do not find a 1941).

82. In re Central States Elec. Corp., 206 F.2d 70 (4th Cir. 1953).

83. In re Los Angeles Lumber Products Co., 37 F. Supp. 708 (S.D. Cal.

84. In re Mountain States Power Co., 35 F. Supp. 307 (D. Del. 1940).

85. In re Midland United Co., 64 F. Supp. 399 (D. Del. 1946), aff'd, 159 F.2d 340 (3d Cir. 1947).

86. Silbiger v. Prudence Bonds Corp., 180 F.2d 917 (2d Cir.), cert. denied, 340 U.S. 813 (1950).

87. In re Equitable Office Bldg. Corp., 83 F. Supp. 531 (S.D.N.Y. 1949).

88. E.g., In re Mountain States Power Co., 35 F. Supp. 307 (D. Del. 1940).

89. A problem of analysis in this area, as well as throughout the Note, has been the fact that many courts fail to articulate whether they are basing their decisions upon commanding statutory language, or upon the presence or absence of equity power to cope with the problem.

90. See text and notes at notes 82-87 supra. In those cases in which compensation has been denied the relationship does not seem to be such that the claimant exercises any substantial control over the trader.

91. In re Midland United Co., 64 F. Supp. 399 (D. Del. 1946), aff'd, 159 F.2d 340 (3d Cir. 1947). .

92. In re Central States Elec. Corp., 112 F. Supp. 281 (E.D. Va. 1953).

93. In re Inland Gas Corp., 73 F. Supp. 785 (E.D. Ky. 1947). 
clear statutory basis for these decisions, they would seem to be based on the "direct or indirect" words appearing in the first sentence of the section.94 One case refused to apply section 249 to a situation in which the wife of a member of a bondholders' committee had traded in the debtor's securities without the knowledge of the claimant.95 The court inferred that had the claimant been aware of his wife's actions compensation might have been denied, not because of section 249, but through the exercise of the bankruptcy court's equity powers. This view is supported in the somewhat similar case of Berner v. Equitable Office Bldg. Corp..$^{96}$ which was written by Judge Learned Hand. There, during reorganization, an attorney for individual shareholders advised his brother-in-law to purchase stock in the debtor. The court held that section 249 by its wording is restricted to trading done by the representative himself; consequently, the attorney did not automatically forfeit all compensation. ${ }^{97}$ But, continued the court, the attorney's conduct amounted to a breach of trust, as a penalty for which equity would reduce the amount of compensation. ${ }^{98}$

Although it has received limited application in other courts, ${ }^{99}$ the device of limiting the application of the statute with a concomitant extension of the bankruptcy courts' equity power is peculiar to the Second Circuit. ${ }^{100}$ Through its use the court avoids the legislative mandate of complete disallowance and imposes its own standard of a reasonable penalty under the circumstances. It is submitted that the majority of courts reach a more

94. See also SEC v. Dumaine, 218 F.2d 308 (1st Cir. 1954) (committee member whose wife traded in debtor's securities denied compensation under Rule U-62(g) (2) quoted at note 49 supra) ; In re Equitable Office Bldg. Co., 83 F. Supp. 531 (S.D.N.Y. 1949) (committee member whose mother traded in the debtor's securities denied compensation).

95. In re Philadelphia \& Reading Coal \& Iron Co., 61 F. Supp. 120 (E.D. $\mathrm{Pa} .1945)$. The court held that the "direct or indirect" provision did not apply to trading by a spouse. That phrase refers only to the nature of the interest acquired (e.g., trading in securities of a subsidiary owned by the debtor). It is submitted that even though the term "direct or indirect" refers to the nature of the interest acquired, see text at note 76 sipra, it may also refer to trading by someone other than the representative. As a matter of semantics or as a matter of logic the court's opinion does not seem correct.

96. 175 F.2d 218 (2d Cir. 1949).

97. See also Nichols v. SEC, 211 F.2d 412 (2d Cir. 1954) (Under facts similar to those in the Berner case the same result was reached under Rule U62(g) (2) quoted at note 49 supra.). Cf. SEC v. Cogan, 201 F.2d 78 (9th Cir. 1951).

98. The court rested this conclusion on two grounds. First, general equitable principles, which are applicable to a claim for compensation from a debtor's estate, forbid a fiduciary to reveal confidential information to outsiders to the detriment of security holders, the beneficiary of the trust. Second, whether or not equity formerly forbade such conduct, the enactment of section 249 imported into general equitable principles a new rule prohibiting leaks of inside information by representatives in reorganization proceedings. Thus, although the court held that section 249 does not apply to the transaction in question, the section did furnish a basis for holding the conduct to be bad in equity.

99. Chicago \& West Towns Ry. v. Friedman, 230 F.2d 364 (7th Cir. 1956); SEC v. Cogan, 201 F.2d 78 (9th Cir. 1951).

100. Nichols v. SEC, 211 F.2d 412 (2d Cir. 1954); Silbiger v. Prudence Bonds Corp., 180 F.2d 917 (2d Cir. 1950) ; Berner v. Equitable Office Bldg. Corp., 175 F.2d 218 (2d Cir. 1949). 
favorable and realistic result than do both those that give complete compensation and those that follow the view of the Second Circuit. Since there is generally a close personal and financial relationship between a husband and wife, since a great deal of money may be at stake, and since it would be practically impossible to prove knowledge and collusion on the part of the husband, it is probable that the décisions of the latter mentioned courts would encourage spouses to testify falsely that they were not aware of the dealings of the other. While the fact that perjury might be utilized to circumvent a statute is not a particularly convincing argument against the sanction, if the perjury would virtually make the sanction a nullity because of the impossibility of proving otherwise, it is submitted that the sanction should not be continued. Even under the view of the Second Circuit a representative might be tempted to take a calculated gamble. As one court so aptly put it, "a fertile field would be opened to a fiduciary to profit from the members of his family and thus to enhance his own economic position by reason of his status as a beneficiary." 101 Aside from exceptional circumstances such as trading by an estranged wife, disallowance would seem proper. ${ }^{102}$

Section $212^{103}$ of the Chandler Act is a second instance in which Congress manifested its intent to prevent trading in the debtor's securities by representatives. It provides:

"The judge . . may limit any claim or stock acquired by such person [agent, attorney, indenture trustee] or committee in contemplation or in the course of the proceedings under this chapter to the actual consideration paid therefor."

Although this section has been infrequently applied to claims presented by representatives, ${ }^{104}$ through its use it is possible to prevent the acquisition

101. In re Midland United Co., 64 F. Supp. 399 (D. Del. 1946), aff'd, 159 F.2d 340 (3d Cir. 1947).

102. Under such circumstances it might be argued that the representative acquired neither a "direct" nor an "indirect" interest in the securities.

103. 52 Stat. 895 (1938), 11 U.S.C. $\$ 612$ (1952).

104. Section 212 and its 77B counterpart, Act of June 7, 1934, c. 424, $\$ 77 \mathrm{~B}(\mathrm{~b})$, 48 .STAT. 913, have received their principal application in cases involving trading in the debtor's securities by officers and directors of the corporation. Complete analysis of these cases is forestalled because of the failure of most courts to articulate the ground upon which the case is based-statutory or equity power. At common law, while there is little doubt that a corporate official may purchase claims against the corporation and enforce them at cost, 3 FLETCHER, CYCIOPEDIA Corporations $\$ 868$ (perm. ed. 1947), his right to enforce at face value claims which he has purchased at a discount has been less certain. Although a few courts have denied insiders any right to profit by such purchases, e.g., Martin v. Chambers, 214 Fed. 769 (5th Cir. 1914); see also 3 FLETCHER, op. cit. supra $\$ 869$, the modern view seems to be that in the case of a solvent going concern in the absence of bad faith or a duty to purchase for the corporation, such claims may be fully enforced. Ballantine, Corporations 209 (1946); 3 Fletcher, op. cit. supra \$ 869. Although several federal courts through either their statutory or equity power set forth the broad proposition that purchases made at a discount while the corporation was "insolvent" could not be enforced at face value, an examination of the facts in each 
of securities at less than face value with the expectation of profiting through recognition at face value ${ }^{105}$ in the reorganization plan. The application of the statute is within the discretion of the court. It covers purchases made prior to the commencement of the proceedings, ${ }^{106}$ but it has been held not applicable to purchases made prior to assuming a representative position. ${ }^{107}$ The sanction has been invoked against members of committees ${ }^{108}$ and attorneys for committees. ${ }^{109}$ On the other hand, the section has been held not applicable to trading by a spouse or child of a committee member. ${ }^{110}$ It is submitted that even though these transactions are not specifically within the wording of the statute, they too should be discouraged as devices employed to circumvent the statutory mandate. Although in all of the cases decided under the section the securities traded were of the same class as those owned by the persons being represented, it is probable, due to its wording, that the statute would be applied if the securities were of a different class. Furthermore, the defenses of good faith, absence of fraud, and favorable results following the transactions do not prevent the application of the statute. ${ }^{111}$

Sections 212 and 249 obviously were enacted because it was deemed by Congress that trafficking in securities by representatives was undesirable. The usual justification for this is that committee members, attorneys, and

case indicates that they dealt only with purchases made after reorganization proceedings had begun, and many of them involved acts of overreaching or bad faith. Monroe v. Scofield, 135 F.2d 725 (10th Cir. 1943); In re The Van Sweringen Co., 119 F.2d 231 (6th Cir. 1941) (indications of fraud); In re Norcor Mfg. Co., 109 F.2d 407 (7th Cir. 1940) (misrepresentation made to sellers of claims); In re Philadelphia \& Western Ry., 64 F. Supp. 738 (E.D. Pa. 1946) (debtor in possession without appointment of trustee); In re McCrory Stores Corp., 12 F. Supp. 267 (S.D.N.Y. 1935) (corporation was also seeking to purchase claims). The Supreme Court has recognized the distinction between purchases, made while the corporation was merely "insolvent" and while in the process of reorganization. In . Manufacturers Trust Co. v. Becker, 338 U.S. 304 (1949), claims of the debtor were purchased at a substantial discount by close relatives and friends of directors of the debtor while the corporation was an insolvent but going concern. The Court allowed the claims to be recognized in full. The implication of the opinion is that a strict limitation on insider's profits may at least be imposed where purchases are made at a time when bankruptcy or reorganization can be shown to be imminent.

105. Cf. In re Philadelphia \& Western Ry., 64 F. Supp. 738 (E.D. Pa. 1946), in which the court allowed the cost of the securities presented less the profits realized on any trading during the proceedings. 1941).

106. In te Los Angeles Lumber Products Co., 46 F. Supp. 77 (S.D. Cal.

107. In re Franklin Bldg. Co., 83 F. Supp. 263 (E.D. Wis. 1948).

108. Ibid.

109. In re Los Angeles Lumber Products Co., 46 F. Supp. 77 (S.D. Cal. 1941).

110. In re Franklin Bldg. Co., 83 F. Supp. 263 (E.D. Wís. 1948). Cf. In re Lorraine Castle Apartments Bldg. Corp., 149 F.2d 55 (7th Cir. 1945) (Section 212 was held not applicable to investors and speculators who bought securities during the proceedings at less than face value. This extension of the statute attempted to prevent the benefits of reorganization from inuring to speculators rather than to bona fide holders.) ; In re Automatic Equipment Mfg. Co., 106 F. Supp. 699 (D. Neb. 1952) (clients of accountant for reorganization trustee not subject to precepts of section 212 in absence of bad faith).

111. In re Los Angeles Lumber Products Co., 46 F. Supp. 77 (S.D. Cal. 1941). 
the like occupy fiduciary positions. Depending upon the case at hand, this relationship has been said to extend to the persons who are being represented, to all of the members of the class whether or not they have authorized the committee or attorney to represent them, and to all security holders in every class. Once the fiduciary relationship has been established, analysis usually proceeds along the lines that it is a breach of trust to personally profit from the position which they occupy at the expense of the beneficiaries of the trust. ${ }^{112}$ It is then an easy matter to hold that sections 212 and 249 were adopted to prevent this conduct. ${ }^{113}$ However, it would seem that placing the justification for these sections on the basis of an existing fiduciary relationship forestalls proper analysis. The term "fiduciary" is simply a label for the legal consequences which result when it is used. Before using the term a satisfactory explanation must be given in the form of the existence of an evil or the strong possibility of an evil arising.

Several reasons may be found in an attempt to justify the congressional action which was taken to prevent trading by representatives. One of the major disadvantages of the reorganization procedure is that it takes so long to conclude a reorganization once the petition has been filed. Ten years is not uncommon, ${ }^{114}$ and the as yet uncompleted reorganization of the Inland Gas Corporation has lasted over twenty-five years ${ }^{115}$ to the date of this writing. If representatives are permitted to trade in securities it might be an incentive for them to further delay the completion of the reorganization. With longer proceedings, more security holders might be tempted to sell their holdings cheaply rather than run the risk of further delay, coupled with the risk that their holdings might not be fully recognized in the final plan. The representatives might delay the proceedings to bring about cheap purchases for themselves. Furthermore, during the course of these pro-

112. E.g., Meyers, Appellate Review of Attorney Allowances in Chapter $X R e-$ organizations, 53 CoLUM. L. REv. 1039 (1953). The author states, at 1043-44, relating to section 249: "Congressional disapproval of the purchase of securities by a fiduciary may be explained on the theory that any person seeking compensation out of the assets of the estate occupies a position of trust with regard to those having an interest in those assets-persons from whose pockets the fee must ultimately come. For an insider . . to purchase securities from members of the class he represents is a breach of his fiduciary duty toward such persons. Congress might well conclude that an appropriate deterrent to such conduct is forfeiture of compensation. But this rationale will not explain the prohibition against the sale of securities, since in selling the fiduciary does not necessarily deal with persons he represents. Perhaps Congress included sales to remove any possible incentive to insiders to manipulate the reorganization for personal gain. A further consideration may have been the depressing effect on the market of sales of a debtor's securities by insiders during reorganization." This might also be applied to section 212. Further discussion in terms of fiduciary conduct may be found in Brown v. Gerdes, 321 U.S. 178 (1944); Pepper v. Litton, 308 U.S. 295 (1939) ; Berner v. Equitable Office Bldg. Corp., 175 F.2d 218 (2d Cir. 1949); In re Mountain States Power Co., 118 F.2d 405 (3d Cir. 1941); In re Los Angeles Lumber Products Co., 46 F. Supp. 77 (S.D. Cal. 1941).

113. Berner v. Equitable Office Bldg. Corp., 175 F.2d 218 (2d Cir. 1949), suggests a second rationale, that trustees are forbidden to buy any part of "trust property." Query, are securities part of the "trust property"? (1956)

114. See Blum, Materials on Insolvency and Reorganization 174-77, 182-87

115. Blasband, Reorgantzation of the Inland Gas Corporatton-A Case STUDX (unpublished thesis in Biddle Law Library of University of Pennsylvania Law School 1958). 
ceedings the representatives might permit "leaks" of information to get to the public which would affect market prices of the debtor's securities. Accordingly, the representatives might either buy, sell or "sell short" in order to profit on the public reaction to the "leaks." With such possibilities of profits the representatives might be tempted to never call a halt to the reorganization. ${ }^{118}$ However, it is submitted that this reason was probably not one which motivated Congress to enact sections 212 and 249. If Congress was desirous of eliminating the delay in reorganization proceedings more direct approaches might have been taken. For example, time limitations could have been established for the filing of plans and for the review of such plans by the Securities and Exchange Commission.

A second reason which might have prompted the adoption of these statutory provisions is the desire to prevent conflicting interests, that is, a situation in which the personal interests of the representative are adverse to the interests of the individuals he represents. This reason has as its basis the practical goal: to produce a "healthy" corporation as a result of the reorganization and to promote the representative system for the protection of unwary security holders. If the finally devised plan was produced by persons representing conflicting interests it is probable that the plan would not be the one which is the most beneficial to the corporation. Similarly, absent confidence in the representative system on the part of security holders, they might feel that the representative would use his position to personally profit at the expense of the class, and hence not carry out his duty to exercise his best efforts to promote the interests of the class. In order to ascertain whether or not this was the true congressional intent each of the eight basic transactions mentioned previously should be examined to determine if within them there is a possibility of a conflict of interests. Starting with the situation in which the representative purchases during the proceedings securities of a class different from those owned by the persons he is representing and retains them throughout the reorganization, there is surely a possibility of conflicting interests. He might seek to have a plan approved which would benefit him personally through his holdings at the expense of the class which he represents. Similarly, if the securities purchased and retained are of the same class as those owned by the persons represented there also might be conflicting interests. The final plan which would satisfy the representative might not necessarily be that which is best for the class. For example, if he bought his securities cheaply he might be satisfied with a cash settlement, while in reality the class would be best served with the receipt of securities in the new corporation. These arguments might also be stretched to cover those situations in which prior-owned securities are sold during the proceedings or securities are both purchased and sold during the proceedings. It could be argued that the securities were either retained or purchased for ultimate recognition

116. See 48 Mich. L. REv. 1194 (1940). 
in the final reorganization plan. If this is so, the aforementioned conflict of interests exists while the securities are retained. The sales were made only because the proceedings took a turn against the interests of the representatives. Moreover, it would also seem clear that those arguments which were applicable to the situation of buying during the proceedings and retaining them until the acceptance of a plan are equally applicable to the situation in which prior-owned securities are retained throughout the proceedings. The same possibility of conflict of interests exists in both cases; yet the latter situation has not been covered by the statute, nor has it been precluded by the cases. If the desire to prevent conflict of interests was the reason for the statutory provisions against trading in the securities of the debtor it would seem that, in order to be consistent in preventing conflicts of interests, the statute should have prohibited men from serving as representatives who own securities of the debtor of any class at any time during the proceeding, regardless of when the securities were acquired.

The third and perhaps the best explanation for the statutory prohibition against representatives trading in the debtor's securities is to prevent the representatives from using their position to personally gain through the use of "inside information" obtained during the proceedings. ${ }^{117}$ Since the statutory provisions cover only trading 'during the proceedings, and since the situation of the representative who has retained prior-owned securities has not been dealt with by the statute or the courts, it would 'seem that the "inside information" argument properly explains why those transactions which are barred by the statute are thus limited. Depending upon the factual situation to which the statute is applied, one may characterize the argument for its use as being based upon either pragmatic or moral considerations. For' example, if a"representative motivated by "inside information" purchases or sells securities of the same class which he represents, and he deals only with depositing members of that class, the persons who have dealt with him suffer a direct monetary injury as a result of his conduct. To prevent this so-called "breach of trust" toward persons who have placed their confidence in him, and hence to foster the representative system, Congress has seen fit to ban this type of transaction. On the other hand, if the trading was done in a class of securities other than those which he represents through the medium of a stock exchange, the pragmatic justification for banning the transaction does not exist. It would seem in the latter case that the only proper justification for its ban must be based on moral considerations. ${ }^{118}$ The argument, although somewhat unsatisfying, must run that it does not seem proper that persons placed in a position whereby information is made readily available to them, and whereby they are adequately compensated for the tasks which they perform, should reap

117. See Manufacturers Trust Co. v. Becker, 338 U.S. 304, 317 (1949) (dissenting opinion).

118. Cf. Yourd, Trading in Securities by Directors, Officers and Stockholders: Section 16 of the Securities Exchange Act, 38 MICH. L. REv: 133 (1939). . The author advances the proposition that trading in any class of securities by an insider, particularly if the trading is done through an exchange, results in a market price for the security which does not represent a true appraisal of its value. 
additional personal profits as a result of their position. While it is probable that not all trading by representatives is motivated by "inside information," due to the practical impossibility in most cases of proving the presence or absence of that motivating factor Congress was probably correct in banning all trading by insiders. ${ }^{119}$

Regardless of the rationale, it-is clear that through sections 212 and 249 Congress has evidenced its intent to discourage trading in the debtor's securities by representatives during reorganization proceedings. However, since a rule of conduct is only as good as the sanctions adopted for its breach, it would seem that sections 212 and 249 do not fully achieve the congressional intent. Section 249 reaches the person who participates in the proceedings primarily for compensation. Realizing that if he trades he will lose his awards he will refrain from any undesirable conduct. Section 212 reaches the person who purchased securities and retained them. Realizing that he cannot profit from this type of conduct he will probably refrain from it. However, neither section 212 nor section 249 reaches the unscrupulous individual who cares little for compensation, but has participated in the proceedings to make a "killing." He will be satisfied to acquire "inside information" and purchase and sell for a profit. At the end of the proceedings he will probably have no securities left (thus making section 212 inapplicable), and not submit a claim for compensation (thus making section 249 inapplicable); however, he will walk away with a large profit. ${ }^{120}$ While this conduct seems reprehensible it is evidently permitted by the Bankruptcy Act. In order to fully achieve the congressional intent of banning all trading by insiders a provision should be adopted to compel an accounting to the debtor's estate for profits made by insiders through trading. Only in this way can complete compliance with the rule be assured. Of course, the bankruptcy court can order an accounting through the exercise of its equity powers, ${ }^{121}$ but due to the apparent reluctance of some courts to exercise these powers, and due to the already existing lack of clarity as to the place of equity power in relation to the statute, ${ }^{122}$ congressional action seems required.

\section{R. R. O.}

119. This argument was adopted by the court in Smolowe v. Delando Corp., 136 F.2d 231 (2d Cir. 1943), decided under the Securities Exchange Act $\$ 16(B), 48$ STAT. 896 (1934), 15 U.S.C. 78p(b) (1952). Section 16(B) was adopted to prevent officers and directors from profiting by trading based on inside information.

120. In In re Philadelphia \& Western Ry., 64 F. Supp. 738 (E.D. Pa. 1946), the claimant had traded for a profit during the proceedings, and retained some securities for the duration of the proceedings. The court allowed his claim at cost less any profits realized in the prior sales.

121. See Young v. Higbee Co., 324 U.S. 204 (1945). Preferred shareholders appealed a decree confirming a plan of reorganization under chapter $X$ upon objections to allowances made to junior claimants. Had the appeal been successful, the preferred shareholders as a class would have benefited. For a consideration they transferred their stock to junior claimants and agreed to abandon the appeal. The Supreme Court held that the profits made from the appeal belong to the preferred shareholders as a class and hence ordered an accounting. The Court said that the equity power of the bankruptcy court is ample to authorize an accounting for the funds in dispute.

122. See notes $89,98,100$ supra. 